\title{
Post-Copulatory Female Choice IN SAgEbRUSH CRICKETS
}

\author{
J. CHADWICK JOHNSON $\downarrow$ TRACIE M. IVY \\ ANNE-KATRIN EGGERT $\downarrow$ SCOTT K. SAKALUK \\ ECOLOGY GROUP $\downarrow$ DEPARTMENT OF BIOLOGICAL SCIENCES \\ ILLINOIS STATE UNIVERSITY $\diamond$ NORMAL
}

\section{$\downarrow \quad$ ABSTRACT}

Male sagebrush crickets (Cyphoderris strepitans) permit females to engage in an unusual form of sexual cannibalism during copulation: females feed on males' fleshy hind wings and ingest haemolymph oozing from the wounds they inflict. These wounds are not fatal, and normally only a portion of the hind wings are eaten at any one mating, so that mated males are not precluded from mating again. However, non-virgin males have fewer resources to offer females than do virgin males, such that females should be selected to preferentially mate with virgin males. Because previous work has indicated a lack of pre-copulatory female choice, we tested the hypothesis that females accept matings with non-virgin males, but discriminate against them afterwards by re-mating sooner than they otherwise would after matings with virgin males. If the last male to copulate with a female prior to egg laying does in fact sire the majority of her offspring, then such post-copulatory behavior would constitute a form of female choice. To test this, we experimentally manipulated both female diet (high protein vs. low protein), and the female's ability to feed on males' wings during mating. We predicted that females prevented from wing feeding and held on a low protein diet would remate sooner than females allowed to wing feed and held on a high protein diet. We measured the amount of time males spent calling in mating trials, and the time to first and second mountings and matings for each female. Our results reveal an effect of wing treatment on the time to first mating. Low protein females mated with winged males significantly more readily than they did with dewinged males. Female diet also had a significant effect on the time to first mounting. Females fed only lettuce (low protein) mounted males sooner than females provisioned with apple and a bee pollen supplement (high protein), indicating that a female's overall nutrient intake may determine her propensity to mate regardless of the mating status of the male she is paired with. No effect of diet or wing treatment was found for time to second mounting or mating.

\section{$\downarrow \quad$ INTRODUCTION}

The extent to which females retain the ability to determine which males sire their offspring through subtle, post-copulatory mechanisms is currently receiving a great deal of interest (Eberhard 1996). As we begin to expand our view of female choice mechanisms, it is becoming increasingly apparent that many mating systems that in the past have been viewed as completely under the control of male-male competition processes, are in fact at least partially influenced by female behaviors as well. Mating systems which are characterized by high degrees of male investment have provided researchers with excellent systems with which to investigate female choice, relative to systems in 
which males donate little more than sperm (Thornhill \& Alcock 1983). For this reason, insect mating systems that involve male-donated, courtship food gifts offer a powerful model system with which to satisfy the two criteria necessary to show adaptive female choice: i) establishing a consistent female preference for certain male traits, and ii) showing that females increase their reproductive success through their mating preferences.

Courtship food gifts can take the form of nuptial prey items (Thornhill 1976), glandular secretions (Alexander 1961), and male body parts (Alexander \& Otte 1967; Sakaluk et al. 1987). One especially noteworthy species in this regard is the sagebrush cricket, Cyphoderris strepitans. In this species, males offer females a spermatophylax, a large gelatinous adjunct to the spermatophore that is consumed by the female after mating. In addition, males also permit females to engage in an unusual form of sexual cannibalism during copulation: females feed on males' fleshy hind wings and ingest haemolymph oozing from the wounds they inflict (Dodson et al. 1983). These wounds are not fatal, and normally only a portion of the hind wings are eaten at any one mating, so that mated males are not precluded from mating again. However, non-virgin males have fewer resources to offer than virgin males, such that females should be selected to preferentially mate with virgin males (Dodson et al. 1983).

Previous studies have shown that virgin males do indeed secure significantly more matings than do non-virgin males, based on their relative abundance in the population (Morris et al. 1989; Snedden 1996). However, the degree to which female choice contributes to this effect remains unclear. Females do not appear to actively reject non-virgins as might have been expected (Snedden \& Sakaluk 1992). Studies to date suggest that females do not differentiate among virgin and nonvirgin males based on qualitative differences in males' songs (Snedden pers. comm.), nor do they appear to discriminate against non-virgin males after pair formation (Snedden \& Sakaluk 1992). A female's ability to feed on a male's hind wings and dismount prior to transfer of the spermatophore, might in fact obviate any advantage to females of pre-copulatory mate choice (Snedden \& Sakaluk 1992).

One alternative that has not been investigated in this species is that females select the sire of their offspring after mating. Post-copulatory female choice can be manifest in a number of different ways. For example, female scorpionflies (Harpobittacus nigriceps) effectively choose males who are able to provide them with the largest nuptial prey items by entering a period of non-receptivity and egg-laying immediately after they mate with these males (Thornhill 1983). This 'cryptic' form of mate choice might explain the presence of male wing investment in $C$. strepitans. Females may accept matings with non-virgin males, but discriminate against them afterwards by re-mating sooner than they otherwise would after matings with virgin males, and/or by delaying egg laying.

The objective of the proposed research was to test the hypothesis that male courtship feeding, and sexual cannibalism in particular, are maintained through a post-copulatory female mating preference of males capable of supplying females with the highest material investment. Specifically, we predicted that females experimentally prevented from wing feeding would remate significantly sooner than females allowed to feed freely, resulting in cryptic female choice of investing males. In addition, we predicted that if overall female nutrient intake is more important to a female's mating and remating behavior than are nutrients derived through sexual cannibalism, then females fed a low protein diet of lettuce should remate more quickly than females fed a high protein diet of apple and bee pollen supplements, regardless of the mating status of their mates.

\section{$\uparrow \quad$ METHODS}

This study was conducted at the University of Wyoming-National Park Service Research Center, the site of previous studies (Snedden \& Sakaluk 1992; Eggert \& Sakaluk 1994; Sakaluk et al. 1995). Male and female crickets were collected early in the breeding season (May-June) from populations within Grand Teton National Park, and transported to the field station. Crickets were maintained according to standard procedures (Snedden \& Sakaluk 1992; Eggert \& Sakaluk 1994). Females were randomly assigned to one of four experimental treatments:

1) females permitted to feed on hind wings and maintained on a low protein diet; 
2) females permitted to feed on hind wings and maintained on a high protein diet;

3) females prevented from wing feeding and maintained on a low protein diet;

4) females prevented from wing feeding and maintained on a high protein diet.

Males paired with females of groups three and four had their hind-wings surgically removed 48 hours prior to the beginning of their mating trials to preclude wing feeding by females.

Experimental pairs were established early in the evening when the crickets become sexually active, and their mating behavior recorded over the following 10 hours using a combination of timelapse video photography and direct observation. Matings were staged in specially constructed, Plexiglas viewing chambers divided into four equal compartments. Throughout direct observations of mating trials, or upon review of the video recordings, we determined the number of 5 minute intervals in which a male called, the number of times males were mounted by females, and the number of mounts leading to successful copulation.

Males and females were weighed before and after mating trials. The sum of female weight gain and male weight loss, divided by two, was used as a crude measure of the benefits gained by females through wing feeding. This measure controls for incidental weight loss through defecation and metabolic activity.

After females of all four groups experienced initial copulations, they were given an opportunity to remate with an unmanipulated virgin male on each subsequent night until re-mating occured or the season ended. The inter-copulatory interval was then used as a measure of a female's willingness to remate. In order to best evaluate a female's propensity to mate and remate, we measured both the time at which the female first mounted the male, and the time at which the female actually mated with the male. Mounting reflects a females readiness to mate, and can be used as a measure of a female's propensity to mate even if the male fails to transfer a spermatophore. In two treatments, we failed to secure an adequate sample of actual matings (i.e. spermatophore transfers), but were able to obtain data on the time at which females were willing to mount males, even if the copulatory act was not completed.

If female post-copulatory behavior is predicated on the level of male nutrient investment and/or the level of overall female nutrient load, then females permitted to feed freely on males' hind wings and/or supplied a high protein diet, should remain unreceptive to subsequent mating attempts for significantly longer periods than females prevented from feeding on males' hind wings and/or supplied with a low protein diet. Moreover, the extent to which male investment (wing material) and overall diet differentially contribute to female nutrition should be reflected in the mass gained by females when one or the other avenue of consumption is prevented. If wing treatment has a greater effect on female body mass than diet manipulation or vice versa, this should be reflected in the length of the period over which females remain unreceptive.

\section{$\downarrow \quad$ RESULTS}

\section{CALLING ACTIVITY OF WINGED AND DE-WINGED MALES}

Treated (de-winged) males did not call significantly less than untreated males (ANOVA $\mathrm{F}=0.18, \mathrm{p}>0.05$ ). According to the 5-minute interval sampling protocol, treated males called on average $60 \%$ of the night $(n=28)$, whereas unmanipulated males called $63 \%$ of the night $(n=83)$. Therefore, differential male mating success cannot be attributed to a lowered calling ability resulting from the surgical removal of males' hindwings.

\section{TIME TO MOUNTNG AND REMOUNTING}

Analysis of variance was used to compare treatments with respect to the time taken by the female to first mount a male, and the time after an initial mating at which the female remounted a new male (see Table 1). Although the data for both of these variables were not normally distributed, logtransformed values were normally distributed and hence were used in all analyses. Diet manipulation had a significant main effect on time to first mount (ANOVA, $F=4.51, p=0.0401$ ), but the effect of wing treatment was marginally short of statistical significance (ANOVA, $F=3.00, p=0.0913$ ); there was no significant interaction between the two main 
Table 1. Mean time to mounting ( $\log _{10}$ transformed) for female Cyphoderris strepitans. Diet had a significant effect on female propensity to mount males $(p<0.05)$, but there was no significant effect of wing treatment $(\mathrm{P}>0.05)$.

\begin{tabular}{llllll}
\hline $\begin{array}{l}\text { Wing } \\
\text { treatment }\end{array}$ & $\begin{array}{l}\text { Diet } \\
\text { treatment }\end{array}$ & $\begin{array}{l}\text { Time (hr.) to } \\
\text { 1st mount }\end{array}$ & \multicolumn{2}{l}{$\begin{array}{l}\text { Time (hr.) to } \\
\text { 2nd mount }\end{array}$} \\
\hline Intact & Low & 0.466 & $(\mathrm{n}=12)$ & 0.557 & $(\mathrm{n}=11)$ \\
Intact & High & 0.774 & $(\mathrm{n}=14)$ & 0.729 & $(\mathrm{n}=13)$ \\
Removed & Low & 0.708 & $(\mathrm{n}=11)$ & 1.078 & $(\mathrm{n}=5)$ \\
Removed & High & 1.113 & $(\mathrm{n}=6)$ & 0.905 & $(\mathrm{n}=3)$
\end{tabular}

effects. Planned contrasts failed to reveal the source of the differences between treatments. However, consistent with the trend found for time to first mating (see below), females held on a high protein diet appeared more reluctant to mate than females held on a low protein diet within both wing treatments. Further study should reveal whether these differences are real.

There were no significant differences across treatments in the time after initial matings at which females remounted new partners. However, low protein females did remount more readily than high protein females within the intact wing treatment. Unfortunately, reduced sample sizes in analyses involving remountings and rematings make interpretation of these results difficult.

\section{TIME TO MATING AND REMATING}

Although a previous study found no evidence of female pre-copulatory discrimination against males lacking hind wings (Eggert \& Sakaluk 1994), we observed a strong mating bias against males whose wings had been experimentally removed (see below). Because of this bias, we obtained a small sample of completed matings in the two treatments involving wingless males. Therefore, we used time-failure analysis to compare treatments because this analsyis permits the inclusion of censored observations (observations in which no mating occurred). As Figure 1. illustrates, the analysis revealed significant differences across treatments in the time taken by females to complete first matings $\left(\chi^{2}=10.26\right.$, $\mathrm{p}=0.0165$ ). Pairwise comparisons were made using planned contrasts between treatments within i) dietary regimes and ii) wing treatments. Within both dietary regimes, females paired with wingless males took much longer to mate than those paired with winged males, but the difference was significant only for females held on the low-protein $\operatorname{diet}\left(\chi^{2}=6.98, \mathrm{p}=0.0082\right)$. Within both wing treatments, there was no difference between lowprotein females and high-protein females in time to first mating, but there was a tendency for females paired with winged males to mate sooner when held on the low-protein diet $\left(\chi^{2}=2.86, p=0.09\right)$. Time failure analysis was also employed to compare treatments with respect to the time taken by females to remate. The analysis revealed no significant differences across treatments $\left(\chi^{2}=4.45\right.$, $\mathrm{p}=0.2169$ ), thereby precluding pairwise comparisons. However, because some females never completed an initial mating, these females were necessarily excluded from the analysis of rematings. The reduced sample sizes make it difficult to draw any firm conclusions. 


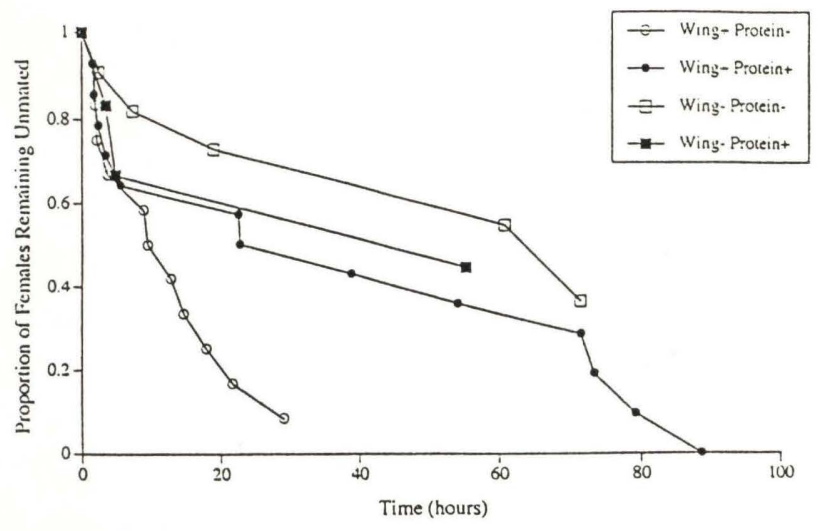

Figure 1. Time to first mating for females held on different diets (high protein $=$ Protein + , low protein $=$ Protein-) and either allowed to feed on females' wings (Wing + ) or precluded from doing so (Wing-).

\section{$\downarrow \quad$ DISCUSSION}

Previous studies have suggested that females do not discriminate among males during courtship based on a male's wing status (Snedden \& Sakaluk 1992; Eggert \& Sakaluk 1994). Indeed, pre-copulatory mate discrimination under natural conditions would appear to be a very costly and inefficient mating strategy for female sagebrush crickets. In the field, a female is required to locate a calling male by walking several meters to his calling perch, often under extremely low temperatures. Given this cost to females, and considering the material gain she can receive even from a non-virgin male, convenience polyandry (Thornhill \& Alcock 1983) would seem more likely than outright mate rejection under natural conditions. Despite this, we found that females are significantly more reluctant to mate with males whose wings have been experimentally removed.

Interestingly, a preference for males with intact wings was not evidenced in our analysis of the time to first mounting. Apparently, while females are discriminating with respect to who they will accept spermatophores from, they mount males without regard to their wing status. This result is consistent with that of a previous study (Eggert \& Sakaluk 1994), in which wingless males were mounted as quickly as their winged counterparts, but transferred significantly fewer spermatophores.
The implication here is that a female's willingness to mount is not influenced by wing status, but in order to retain a female long enough to transfer a spermatophore, a male must possess sufficient hind wing material. This interpretation is further complicated by evidence showing that males with wing material can secure females with a pinching device known as the gin trap, and apparently force copulation upon them (Sakaluk et al. 1995).

The evidence for pre-copulatory female choice does not preclude a role for post-copulatory mechanisms of discrimination. However, the existence of pre-copulatory mating discrimination makes it extremely difficult to identify potential differences in the remating propensity of females. Because of the bias against males lacking hind wings, we were left with small sample sizes in both treatments involving these males. A female's unwillingness to mate the first time with a wingless male makes any analysis of her willingness to mate a second time impossible.

The most compelling result from this study arose from our manipulation of female diet. Our results suggest that females lacking in protein mate more readily than do females held on a high protein diet, regardless of the mating status of the male they are paired with. While these differences are not significant in all instances, they are consistent with the idea that overall female nutrient load affects mate choice and perhaps remating propensity.

\section{$\downarrow$ ACKNOWLEDGEMENTS}

We thank Angelo Capparella for the use of his balance. The study was supported by grants from the University of Wyoming-National Park Service Research Center and Illinois State University to SKS, and by Phi Sigma Biological Honors Society to JCJ.

\section{$\downarrow$ REFERENCES}

Alexander, R.D. 1961. Aggresiveness, territoriality, and sexual behavior in field crickets (Orthoptera:Gryllidae). Behaviour, 17:130223. 
Alexander, R.D. \& D. Otte. 1967. The evolution of genitalia and mating behavior in crickets (Gryllidae) and other Orthoptera. Miscellaneous Publications of the Museum of Zoology, University of Michigan, 133:1-62.

Dodson G., G.K. Morris \& D.T. Gwynne. 1983. Mating behavior in the primitive orthopteran genus Cyphoderris (Haglidae). In Orthopteran mating systems: sexual competition in a diverse group of insects, ed. D.T. Gwynne \& G.K. Morris. Boulder, Colorado: Westview Press.

Eberhard, W.G. 1996. Female Control: Sexual Selection by Cryptic Female Choice. Princeton, NJ: Princeton University Press.

Eggert A.K. \& Sakaluk S.K. 1994. Sexual cannibalism and its relation to male mating success in sagebrush crickets, Cyphoderris strepitans (Haglidae: Orthoptera). Animal Behavior, 47:1171-1177.

Morris, G.K., D.T. Gwynne, D.E. Klimas, \& S.K. Sakaluk. 1989. Virgin male mating advantage in a primitive acoustic insect (Orthoptera: Haglidae). Journal of Insect Behavior, 2:173-184.

Sakaluk, S.K., W.A. Snedden, K.A. Jacobson, A-K Eggert. 1995. Sexual competition in sagebrush crickets: must males hear calling rivals? Behavioral Ecology, 6:250-257.
Sakaluk, S.K., G.K. Morris, \& W.A. Snedden 1987. Mating and its effect on acoustic signalling behaviour in a primitive orthopteran, Cyphoderris strepitans (Haglidae): the cost of feeding females. Behavioral Ecology Sociobiology, 21:173178.

Snedden, W.A. 1996. Lifetime mating success in male sagebrush crickets: sexual selection constrained by a virgin male mating advantage. Animal Behavior, 51:11191125.

Snedden, W.A. \& Sakaluk, S.K. 1992. Acoustical signalling and its relation to male mating success in sagebrush crickets. Animal Behavior, 44: 633-639.

Thornhill, R. 1976. Sexual selection and nuptial feeding behavior in Bittacus apicalis (Insecta: Mecoptera). American Naturalist, 110: $529-548$.

Thornhill, R. 1983. Cryptic female choice and its implications in the scorpionfly Harpobittacus nigriceps. American Naturalist, 122:765-788.

Thornhill, R. \& Alcock, J. 1983. The evolution of insect mating systems. Cambridge, MA: Harvard University Press. 